Thorax (1973), 28, 41.

\title{
Thrombo-embolic complications of the cloth-covered Starr-Edwards prostheses No. 2300 aortic and No. 6300 mitral
}

\author{
J. CLELAND and P. J. MOLLOY \\ Cardiac Surgical Unit, Royal Victoria Hospital, Belfast
}

The thrombo-embolic complications of the cloth-covered Starr-Edwards prostheses No. 2300 aortic and No. 6300 mitral followed for an average of 14 months in 155 patients are reviewed. There was a high incidence of early fatal and disabling thrombo-embolus in patients having mitral valve replacement. Late emboli were more common after aortic valve replacement. Anticoagulant control was unsatisfactory and not without hazards.

Thrombo-embolism is a serious limiting factor in the success of operations for prosthetic valve replacement. Ball variance, the higher incidence of thrombo-embolism with previous StarrEdwards prostheses (No. 1000 aortic and No. 6000 mitral), and the difficulties with long-term anticoagulant control (Duvoisin, Brandenburg, and McGoon, 1967; Roberts, Levinson, and Morrow, 1970 ; Matloff et al., 1969 ; Chin, Harrison, Blakenhorn, and Moacanin, 1971; Starr, Herr, and Wood, 1967) have prompted modifications and the development of the cloth-covered Starr-Edwards prostheses No. 2300 aortic and No. 6300 mitral (Braunwald and Bonchek, 1967 ; Hodam, Starr, Raible, and Griswold, 1970 ; Hodam, Starr, Herr, and Pierie, 1969).

Enthusiastic reports of the reduction in thrombo-embolism with this prosthesis (Hodam et al., 1969) encouraged us to use this valve extensively.

\section{MATERIAL AND METHODS}

From June 1968 to December 1969, 164 patients underwent valve replacement with the use principally of the cloth-covered Starr-Edwards prostheses No. 2300 and No. 6300 in 172 operations (Table I). Eight patients had two operations performed. A total of 235 valves were replaced. Ten patients had a Starr-Edwards disc valve inserted (No. 6500) and in five patients it was the only valve inserted. Three patients had a University of Cape Town valve (Barnard, Goosen, Holmgren, and Schrire, 1962) inserted in the tricuspid area in association with Starr-Edwards mitral valve replacement.

In the latter part of the study a modification of the cloth-covered prosthesis- the composite seat valve No. 2310 aortic and No. 6310 mitral-was used, when it became available, in 19 patients. In 12 patients it was the only valve used and a total of 24 of these valves were inserted.

Our perfusion technique used a disposable bubble oxygenator ${ }^{1}$ and Sarns roller pumps ${ }^{2}$ with an arterial flow rate of $2.41 / \mathrm{min} / \mathrm{m}^{2}$ with moderate hypothermia to $30-32^{\circ} \mathrm{C}$. The ascending aorta was used for arterial cannulation in all but four patients in whom the right external iliac artery was used.

The mitral valve was replaced using a transseptal approach (Brock, 1956). In our early experience interrupted sutures were used to insert the valve, but in the majority of cases a continuous suture technique was used for fixation of the valve.

For aortic valve insertion, with perfusion of both coronary arteries, the aorta was opened through an oblique aortotomy and the valve was sited with interrupted sutures of $00 \mathrm{Ethiflex}^{3}$. The tricuspid valve was inserted using interrupted sutures in the area of the bundle of $\mathrm{His}$ and a continuous suture for the remainder of the valve ring.

Postoperatively anticoagulant warfarin sodium was started on the third or fourth postoperative day, day 1 being the day of operation. Most patients started therapy on the third day. An attempt was made in consultation with the haematologists to stabilize the prothrombin time at greater than $70 \mathrm{sec}$, that is, less than $20 \%$ of normal, and if possible between 10 and $20 \%$. A control level was reached by the seventh postoperative day in most cases.

All patients received anticoagulants. The records of each patient were reviewed and all patients were seen postoperatively at 6-week, 3-month, and 6-month intervals. The follow-up time ranged from 5 to 26 months, with a mean of 14 months.

In approximately half of the cases anticoagulant control was carried out in the hospital where the operation was performed. The detailed anticoagulant 1Rygg-Kyvsgaard disposable bubble oxygenator (Polystan, Copen-

2Sarns Inc., 6200 Jackson Road, Ann Arbor, Mich, U.S.A.
3Ethicon Lid., Scotland 
T A B L E I

RESULTS OF CLOTH-COVERED STARR-EDWARDS PROSTHESIS

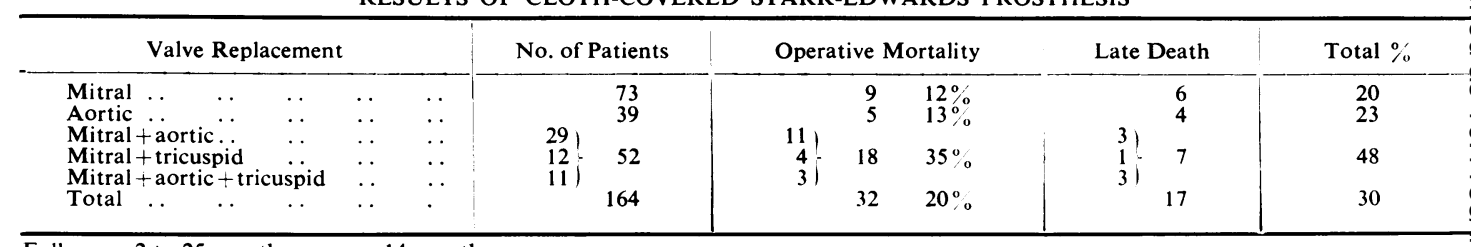

Follow-up 2 to 25 months; mean $=14$ months

record was reviewed in those patients seen at this hospital. Control was considered inadequate if more than one out of 10 estimations were outside the limits already mentioned or if anticoagulants had been discontinued for any reason. The status of anticoagulants was available at the time of thrombo-embolism in most patients.

The diagnosis of embolus was made clinically and confirmed where appropriate by necropsy findings. Embolism occurring as the result of a perfusion accident, that is, air or calcific emboli, or as a result of bacterial endocarditis was excluded from the study. All embolic episodes were arbitrarily divided into definite and probable, depending on the certainty of the episode, but all were included in the calculation of the incidence of thrombo-embolism.

The patient incidence was calculated from the first episode if more than one occurred. All episodes were used in calculating the sites of emboli. In the calculations four patients who died within 24 hours of operation and the five patients who had single Starr-Edwards disc valves inserted in the mitral area were excluded. In those patients who died late postoperatively, the time of death from operation was used in calculating the mean follow-up time. Early thrombo-embolism was that occurring in hospital or during the first postoperative month. The incidence of late thromboembolism was calculated from the number of patients alive one month postoperatively.

\section{RESULTS}

There were 27 embolic episodes in 23 patients, an incidence of $15 \%$ (Table II). Of these, 12 occurred in 11 patients in the early postoperative period (up to the thirtieth postoperative day), an incidence of $7 \%$. In the follow-up period there were 15 episodes in 12 patients, an incidence of $9 \%$ or 1 per 115 patient-months of follow-up.

EARLY EMBOLI Of the early emboli, 10 were definite and two probable (Table III). Six patients had mitral valve replacements alone, three mitral and aortic valve replacements, one mitral and tri-
T A B L E I I

INCIDENCE OF THROMBO-EMBOLISM WITH CLOTHA COVERED STARR-EDWARDS PROSTHESIS IN 155 PATIENTS

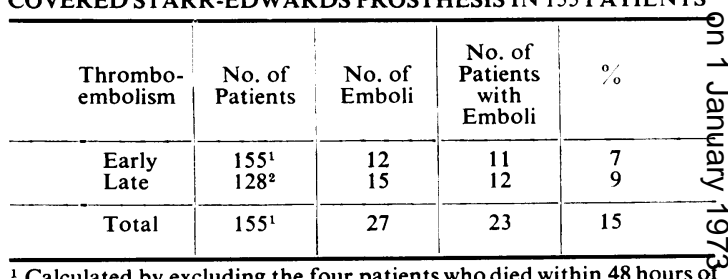

${ }^{1}$ Calculated by excluding the four patients who died within 48 hours of operation (one aortic valve replacement, one triple valve replacement and two aortic and mitral valve replacements). Excluded also are the five patients who had a single Starr-Edwards disc valve inserted i the mitral area.

${ }_{2}$ Calculated from the number of patients who were alive one mont postoperatively.

cuspid valve replacement, and one aortic valve replacement. The sites of the emboli were ceres bral in nine, renal in two, and axillary artery in one. These episodes occurred as early as the fourth postoperative day and all occurred withis two weeks with a mean time of seven days. Seveg were fatal and represent $22 \%$ of an early operan tive mortality of 32 patients. Two of the norb fatal episodes caused severe residual disability. One patient required an above-elbow amputatiog of the left arm after two attempts at brachial embolectomy were unsuccessful. The other patien has a residual hemiplegia with dysphasia.

Anticoagulant control was unsatisfactory im nine of the 11 patients. At the time of the fou non-fatal episodes, anticoagulant control wa unsatisfactory in two. In one of these a ther peutic level had not been reached, and in the othe्e

T A B L E I I I

EARLY THROMBO-EMBOLISM IN 155 PATIENTS

\begin{tabular}{|c|c|c|c|}
\hline No. of patients & 11 & $\begin{array}{l}6 \text { Mitral } \\
3 \text { Mitral + aortic } \\
1 \text { Aortic } \\
1 \text { Mitral + tricuspid }\end{array}$ & $7 \%$ \\
\hline No. of emboli & 12 & $\begin{array}{l}9 \text { Cerebral } \\
2 \text { Renal } \\
1 \text { Axillary artery }\end{array}$ & \\
\hline Defir & -10 & Probable -2 & \\
\hline $\begin{array}{l}\text { Onset } \\
\text { Outcome } \\
\text { Anti-coagulant }\end{array}$ & \multicolumn{3}{|c|}{$\begin{array}{l}\text { 4-14 (mean 7) days } \\
\text { Fatal }-7 \text { Non-fatal }-4 \\
\text { ntrol: Satisfactory } 2 ; \text { Unsatisfactory } 9\end{array}$} \\
\hline
\end{tabular}


T A B LE IV

EARLY FATAL THROMBO-EMBOLISM

\begin{tabular}{|c|c|c|c|c|c|c|}
\hline \multirow[b]{2}{*}{ Patient } & \multirow[b]{2}{*}{ Valve Replacement } & \multirow{2}{*}{$\begin{array}{c}\text { Site of Thrombus } \\
\text { at Necropsy }\end{array}$} & \multirow{2}{*}{$\begin{array}{l}\text { Presenting } \\
\text { Symptom }\end{array}$} & \multicolumn{3}{|c|}{ Time in Days } \\
\hline & & & & $\begin{array}{l}\text { Onset of } \\
\text { Symptoms }\end{array}$ & Embolism & $\begin{array}{l}\text { Anticoagulant } \\
\text { Control Obtained }\end{array}$ \\
\hline $\begin{array}{l}1 \\
2 \\
3 \\
4 \\
5 \\
6 \\
7\end{array}$ & $\begin{array}{l}\text { Mitral } \\
\text { Aortic } \\
\text { Mitral + aortic } \\
\text { Mitral + tricuspid } \\
\text { Mitral + aortic } \\
\text { Mitral + aortic } \\
\text { Mitral }\end{array}$ & $\begin{array}{l}\text { Atrium (L) } \\
\text { Ventricle (L) } \\
\text { No necropsy } \\
\text { Mitral and tricuspid valves } \\
\text { Mitral and aortic valves } \\
\text { Mitral and aortic valves } \\
\text { Mitral valve }\end{array}$ & $\begin{array}{l}\text { Cerebral } \\
\text { Cerebral } \\
\text { Cerebral } \\
\text { Cerebral } \\
\text { Pulmonary } \\
\text { Pulmonary } \\
\text { Pulmonary }\end{array}$ & $\begin{array}{r}4 \\
12 \\
6 \\
12 \\
2-3 \\
2-3 \\
2-3\end{array}$ & $\begin{array}{r}4 \\
12 \\
6 \\
12 \\
4 \\
5 \\
7\end{array}$ & $\begin{array}{c}\text { Uncontrolled } \\
\text { Uncontrolled } \\
13 \\
17 \\
6 \\
6 \\
5\end{array}$ \\
\hline
\end{tabular}

it had been reached earlier but was uncontrolled at the time of embolism.

Necropsy was performed in six of the seven cases with early fatal episodes (Table IV). In none was muscular restriction of ball movement implicated as a cause of thrombus formation (Spencer et al., 1970). There were four double valve replacements and three single valve replacements. In four patients (Nos 4, 5, 6, and 7) thrombus was present on the valve. In patients 5 and 6 , who had mitral and aortic valve replacements, all four valves were almost completely occluded by thrombus. In patient 7 with a single mitral valve replacement, the valve was similarly affected. In patients 5, 6, and 7, the presenting symptoms were those of increasing respiratory distress with bronchospasm and pulmonary oedema and were associated with bizarre dysrhythmias. These symptoms occurred two to three days postoperatively and preceded the onset of embolism. The embolic episodes in two cases were minor.

Of the 12 patients who had composite seat valves inserted, one (patient 5), who had two such valves inserted, had an early embolus. This is an incidence of $8 \%$, which is similar to that of the non-composite seat valves but the figures here are small and of doubtful statistical significance.

In patients $1,2,3$, and 4 (Table IV) the presenting symptoms were cerebral, the times of onset and of embolism being coincidental. Patient 1 had fresh thrombus in both atrial appendages and on the suture line in the atrial septum. In patient 2, who had an aortic valve replacement, there was thrombus at the site of myocardial infarction resulting from injury to the right coronary artery during coronary perfusion. Patient 4, who had mitral and tricuspid valve replacements, showed a minor amount of thrombus on the mitral valve, but the tricuspid valve was almost completely occluded. This patient had a minor embolus on the twelfth postoperative day but was admitted to hospital four months later in extremis with cardiogenic shock and evidence of tricuspid obstruction. The sounds of the tricuspid disc valve had disappeared and on screening the poppet was immobile. Emergency operation was carried out and the tricuspid valve was replaced by a Starr-Edwards ball valve prosthesis. This patient died 24 hours later. At necropsy there was histological evidence that clotting on both valves had occurred early, as mature fibrous tissue was present.

In these seven fatalities, anticoagulant control level had not been reached before the onset of symptoms (last column, Table IV). In patients 2 and 4 a satisfactory level had not been achieved. In the other five patients a control level could not have been achieved using our present technique at the time of the onset of symptoms or embolism.

LATE EMBOLI Fourteen of the 15 late thromboembolic episodes which occurred in 12 patients were of a minor nature ; only nine were definite (Table V). These produced transient symptoms lasting less than 24 hours and left no residual defects.

T A B L E V

LATE THROMBO-EMBOLISM IN 128 PATIENTS

\begin{tabular}{|c|c|c|c|}
\hline No. of patients & 12 & $\begin{array}{l}5 \text { Mitral } \\
6 \text { Aortic } \\
1 \text { Mitral +aortic }\end{array}$ & $9 \%$ \\
\hline $\begin{array}{r}\text { No. of emboli } \\
\text { Defi }\end{array}$ & ite- & $\begin{array}{l}11 \text { Cerebral } \\
1 \text { Splenic } \\
1 \text { Renal } \\
1 \text { Coronary artery } \\
1 \text { Femoral artery } \\
9 \text { Probable }\end{array}$ & $\begin{array}{l}\text { 1/115 patient- } \\
\text { months } \\
-6\end{array}$ \\
\hline $\begin{array}{l}\text { Onset: } \\
\text { Outcome: } \\
\text { Anti-coagulant }\end{array}$ & & $\begin{array}{l}5 \text { weeks to } 1 \text { year ( } \\
\text { Fatal }-4 \\
\text { Satisfactory } 4 ;\end{array}$ & $\begin{array}{l}\text { nean } 6 \text { months) } \\
\text { fatal-8 } \\
\text { nsatisfactory } 7\end{array}$ \\
\hline
\end{tabular}

There were five mitral valve replacements, six aortic valve replacements, and one mitral and aortic valve replacement in this group. Of these 12 patients, one late embolism occurred in a patient with a composite seat aortic valve (No. 2310) but this patient also had an older type mitral valve inserted (No. 6300). The sites of the emboli were cerebral in 11 and splenic, renal, coronary artery, and femoral artery in one case 
T A B L E V I

INFLUENCE OF SITE OF VALVE REPLACEMENT ON THROMBO-EMBOLISM IN 155 PATIENTS

\begin{tabular}{|c|c|c|c|c|c|c|}
\hline $\begin{array}{c}\text { Valve } \\
\text { Replacement }\end{array}$ & No. of Patients ${ }^{1}$ & $\underset{\text { (no.) }}{\text { Early Emboli }}(\%)$ & No. of Patients ${ }^{2}$ & $\begin{array}{l}\text { Late Emboli } \\
(\text { (no.) }\end{array}$ & (no.) & $(\%)$ \\
\hline $\begin{array}{l}\text { Single mitral } \\
\text { Single aortic }\end{array}$ & $\begin{array}{l}68 \\
38\end{array}$ & $\begin{array}{l}6 \\
1\end{array}$ & $\begin{array}{l}60 \\
34\end{array}$ & $\begin{array}{r}8 \\
18\end{array}$ & 11 & $\begin{array}{l}16 \\
18\end{array}$ \\
\hline $\begin{array}{l}\text { Total mitral } \\
\text { Total aortic }\end{array}$ & $\begin{array}{r}117 \\
75\end{array}$ & $\begin{array}{r}10 \\
4\end{array}$ & $\begin{array}{l}94 \\
60\end{array}$ & $\begin{array}{r}6 \\
12\end{array}$ & $\begin{array}{l}16 \\
11\end{array}$ & $\begin{array}{l}14 \\
15\end{array}$ \\
\hline
\end{tabular}

${ }^{1}$ Calculated by excluding the four patients who died within 48 hours of operation (one aortic valve replacement, one triple valve replacement and two aortic and mitral valve replacements). Excluded also are the five patients who had a single Starr-Edwards disc valve inserted in the mitral area.

${ }^{2}$ Calculated from number of patients who were alive one month postoperatively.

each. The mean time of onset was six months from operation, with a range from five weeks to one year.

At the time of embolism, anticoagulant control was satisfactory in only four patients and unsatisfactory in seven. In the other patient it was unknown.

There were four fatalities in the group, but only one was the result of embolism. Anticoagulants were temporarily discontinued two weeks before the fatal coronary artery embolism, which was confirmed at necropsy, as was a slightly older renal embolus. There was a minor amount of thrombus on the aortic prosthesis at necropsy. A second patient, who had two minor cerebral embolic episodes, was negligent about taking his anticoagulants, having discontinued them on several occasions. He died suddenly one year postoperatively. Permission for necropsy was not obtained, but his death was presumed to be embolic in origin. An embolism occurred in a third patient whose anticoagulant control was unsatisfactory. His dosage was increased and he died two weeks later from a cerebral haemorrhage as a direct result of anticoagulant overdosage. The fourth patient died of bacterial endocarditis one year after a probable minor embolus. Two further patients died as a result of overdosage with anticoagulants, both suffering a cerebral haemorrhage.

The influence of the site of valve replacement on thrombo-embolism was investigated (Table VI). Patients who had a mitral valve only replaced had a $9 \%$ incidence of early emboli, whereas patients who had an aortic valve only replaced had a $3 \%$ incidence. When all patients who had a mitral valve replaced alone or in combination with other valves are compared with those who had an aortic valve similarly replaced, the relationship is similar at 9 and $5 \%$ respectively.

With late emboli the relationship is reversed. Eight per cent of patients with single mitral valve replacements and $18 \%$ of patients with single aortic valve replacements had emboli. When all mitral and aortic valve replacements are com pared, the relationship remained $6 \%$ and $12 \%$ 은 respectively.

The incidence of early embolus was similar in single and multiple valve replacements, $7 \%$ and $8 \%$ respectively, but late emboli were less com mon with multiple valve replacements $(3 \%)$ compared to single valve replacement $(12 \%)$.

Factors that may have influenced the incidence of thrombo-embolism were investigated. These included a past history of thrombo-embolism, as previous mitral valvotomy, the size of the valves inserted, the presence of thrombus in the lef:ै atrium at operation, valve calcification, atria $\mathbb{B}$ fibrillation, marked enlargement of the left atrium $\overrightarrow{\overrightarrow{0}}$ and postoperative haemorrhage.

In the patients who had a single aortic valve? replaced and a postoperative embolus, only valve्?. size, valve calcification, and atrial fibrillation were relevant as the other factors were absent. One patient had an early embolus with the onset of atrial fibrillation. Ten other patients having aortic valve replacements developed transient atriaf. fibrillation early after operation without emboliza tion. Two of the six patients with late embolk who had aortic valve replacements were in atriaf fibrillation, but in the non-embolic group theres were no patients with atrial fibrillation. Neither valve size nor calcification had any influence on the incidence of thrombo-embolism.

In patients who had their mitral valves replaced atrial fibrillation did not appear to influence the incidence of thrombo-embolism. Eighty-three pe cent of patients with early emboli had atriab fibrillation, $82 \%$ of all patients with emboli were in atrial fibrillation, and $84 \%$ of patients who ${ }^{\circ}$ did not have emboli were so afflicted (Table VII)

A previous history of thrombo-embolism wao just as common in patients with or withou是 emboli. In the three groups mentioned, the per $\mathbb{\mathbb { Q }}$ centages were $17 \%, 18 \%$, and $16 \%$ respectivelyo Although nine patients were found to have leff atrial thrombus at operation, no atrial clot was 
T A B LE VII

FACTORS INFLUENCING THROMBO-EMBOLISM IN 68 SINGLE MITRAL VALVE REPLACEMENTS

\begin{tabular}{|c|c|c|c|c|c|c|c|c|c|c|c|c|c|}
\hline \multirow{2}{*}{\begin{tabular}{l}
\multicolumn{1}{c}{ Group } \\
Early emboli \\
All emboli \\
No emboli
\end{tabular}} & \multirow{2}{*}{$\begin{array}{r}\text { No. } \\
\begin{array}{r}6 \\
11 \\
57\end{array}\end{array}$} & \multicolumn{2}{|c|}{$\begin{array}{c}\text { Atrial } \\
\text { Fibrillation } \\
\text { (no.) }(\%)\end{array}$} & \multicolumn{2}{|c|}{$\begin{array}{l}\text { Past History } \\
\text { of Embolism } \\
\text { (no.) (\%) }\end{array}$} & \multicolumn{2}{|c|}{$\begin{array}{c}\text { Previous Mitral } \\
\text { Valvotomy } \\
\text { (no.) }(\%)\end{array}$} & \multicolumn{2}{|c|}{$\begin{array}{c}\text { Valve } \\
\text { Calcification } \\
\text { (no.) }(\%)\end{array}$} & \multicolumn{2}{|c|}{$\begin{array}{c}\text { Left Atrial } \\
\text { Enlargement } \\
(\text { no. })\end{array}$} & \multicolumn{2}{|c|}{$\begin{array}{l}\text { Postoperative } \\
\text { Haemorrhage } \\
\text { (no.) (\%) }\end{array}$} \\
\hline & & $\begin{array}{r}5 \\
9 \\
48\end{array}$ & $\begin{array}{l}83 \\
82 \\
84\end{array}$ & $\begin{array}{l}1 \\
2 \\
9\end{array}$ & $\begin{array}{l}17 \\
18 \\
16\end{array}$ & $\begin{array}{r}0 \\
3 \\
22\end{array}$ & $\begin{array}{r}0 \\
27 \\
40\end{array}$ & $\begin{array}{r}1 \\
2 \\
21\end{array}$ & $\begin{array}{l}17 \\
18 \\
37\end{array}$ & $\begin{array}{r}4 \\
8 \\
23\end{array}$ & $\begin{array}{l}66 \\
73 \\
40\end{array}$ & $\begin{array}{r}3 \\
3 \\
10\end{array}$ & $\begin{array}{l}50 \\
27 \\
18\end{array}$ \\
\hline
\end{tabular}

T A B LE V I I I

FACTORS INFLUENCING THROMBO-EMBOLISM IN 117 PATIENTS WITH SINGLE OR COMBINED MITRAL VALVE REPLACEMENTS

\begin{tabular}{|c|c|c|c|c|c|c|c|c|c|c|c|c|c|}
\hline Group & No. & \multicolumn{2}{|c|}{$\begin{array}{c}\text { Atrial } \\
\text { Fibrillation } \\
\text { (no.) }(\%)\end{array}$} & \multicolumn{2}{|c|}{$\begin{array}{l}\text { Past History } \\
\text { of Embolism } \\
\text { (no.) ( } \%)\end{array}$} & \multicolumn{2}{|c|}{$\begin{array}{l}\text { Previous Mitral } \\
\text { Valvotomy } \\
\text { (no.) }(\%)\end{array}$} & \multicolumn{2}{|c|}{$\begin{array}{c}\text { Valve } \\
\text { Calcification } \\
\text { (no.) }(\%)\end{array}$} & \multicolumn{2}{|c|}{$\begin{array}{c}\text { Left Atrial } \\
\text { Enlargement } \\
\text { (no.) }(\%)\end{array}$} & \multicolumn{2}{|c|}{$\begin{array}{l}\text { Postoperative } \\
\text { Haemorrhage } \\
\text { (no.) (\%) }\end{array}$} \\
\hline $\begin{array}{l}\text { Early emboli } \\
\text { All emboli } \\
\text { No emboli }\end{array}$ & $\begin{array}{r}10 \\
16 \\
101\end{array}$ & $\begin{array}{r}9 \\
14 \\
83\end{array}$ & $\begin{array}{l}90 \\
87 \\
82\end{array}$ & $\begin{array}{r}3 \\
5 \\
18\end{array}$ & $\begin{array}{l}30 \\
31 \\
19\end{array}$ & $\begin{array}{r}2 \\
6 \\
45\end{array}$ & $\begin{array}{l}20 \\
38 \\
45\end{array}$ & $\begin{array}{r}3 \\
5 \\
45\end{array}$ & $\begin{array}{l}30 \\
31 \\
45\end{array}$ & $\begin{array}{r}5 \\
10 \\
36\end{array}$ & $\begin{array}{l}50 \\
63 \\
37\end{array}$ & $\begin{array}{r}3 \\
3 \\
21\end{array}$ & $\begin{array}{l}30 \\
19 \\
21\end{array}$ \\
\hline
\end{tabular}

found in any patient who subsequently had an embolus. Calcification of the mitral valve or a previous valvotomy did not predispose to embolism; these conditions were present in $40 \%$ of patients without embolus but in only $27 \%$ of those with emboli.

Marked left atrial enlargement occurred in $66 \%$ of patients with early emboli, in $73 \%$ of the all embolic group, but in only $40 \%$ of the non-embolic group.

Postoperative haemorrhage requiring re-operation was more common in the group with early emboli than in the control group- $50 \%$ as compared to $18 \%$.

In comparing the non-embolic group of patients who had a mitral valve replacement either alone or in combination with other valve replacements with the embolic group the relationship still holds (Table VIII), except that patients with a past history of embolus are more common in the embolic group (30\% and $31 \%$ respectively) than in the non-embolic group (19\%). This discrepancy may be due to the small number of patients in the embolic group.

The influence of valve size in the mitral area on thrombo-embolism was investigated, as it was thought that the smaller valves might cause stasis

T A B L E I X

INFLUENCE OF VALVE SIZE ON THE INCIDENCE OF THROMBO-EMBOLISM IN 68 SINGLE MITRAL VALVE
REPLACEMENTS

\begin{tabular}{|c|c|c|c|c|c|}
\hline Thrombo-embolism & No. & \multicolumn{2}{|c|}{$\begin{array}{l}\text { Size } 2 \text { or } 3 \\
\text { (no.) }\end{array}$} & \multicolumn{2}{|c|}{$\begin{array}{c}\text { Size } 4 \\
\text { (no.) }(\%)\end{array}$} \\
\hline $\begin{array}{l}\text { Early } \\
\text { Early and la te } \\
\text { No embolus }\end{array}$ & $\begin{array}{r}6 \\
11 \\
57\end{array}$ & $\begin{array}{r}4 \\
5 \\
25\end{array}$ & $\begin{array}{l}67 \\
46 \\
44\end{array}$ & $\begin{array}{r}2 \\
6 \\
32\end{array}$ & $\begin{array}{l}33 \\
55 \\
56\end{array}$ \\
\hline
\end{tabular}

and hence thrombus formation (Table IX). But valve size did not appear to be important except with early emboli when patients who had had a smaller valve inserted appeared to be more prone to embolus formation. This was not statistically significant.

Anticoagulant control in the patients without emboli who were followed at our own clinic (approximately half of all the patients) was unsatisfactory in all patients followed as none fell within the strict limits described. At the time of embolism only six patients out of 22 were in satisfactory anticoagulant control.

T A B L E X

INFLUENCE OF VALVE SIZE ON THE INCIDENCE OF THROMBO-EMBOLISM IN 117 MITRAL VALVE REPLACEMENTS

\begin{tabular}{l|c|cc|cc}
\hline Thrombo-embolism & No. & \multicolumn{2}{|c|}{ Size 2 } & or 3 & \multicolumn{2}{|c}{ Size 4 } \\
& & (no.) & $(\%)$ & (no.) & $(\%)$ \\
\hline Early & 10 & 4 & 40 & 6 & 60 \\
Early and late & 16 & 6 & 38 & 10 & 62 \\
No embolus & 101 & 54 & 53 & 47 & 47 \\
\hline
\end{tabular}

\section{DISCUSSION}

The cloth-covered Starr-Edwards prostheses No. 2300 aortic and No. 6300 mitral, specifically designed to reduce the incidence of thromboembolism and to eliminate the need for anticoagulants (Braunwald and Bonchek, 1967; Hodam et al., 1970), do not fulfil their promise with or without satisfactory anticoagulant therapy. The high incidence of early and disabling thrombo-embolism is similar to, and in some cases greater than, that reported for the earlier ball valve prosthesis (Hodam et al., 1969; Kahn et al., 
1966; Duvoisin et al., 1967). The episodes are more severe and produce greater disability. The fatalities from embolism represent $22 \%$ of the operative mortality. Only two patients out of 11 with early emboli had transient symptoms with minimal disability. The incidence of early thrombo-embolism in our series $(7 \%)$ is similar to that of Hodam at 6\% (Hodam et al., 1969), using the same prosthesis. The incidence of early embolism after aortic valve replacement is low $(3 \%)$ and similar to that of the earlier StarrEdwards prostheses No. 1000 and No. 1200 (Hodam et al., 1969). The mitral prosthesis appears to be at greater risk as a site of thrombus formation early postoperatively. Our incidence of $9 \%$ is similar to that with the earlier No. 6000 prosthesis but less than the $11 \%$ reported by Hodam et al. (1969) with the cloth-covered prosthesis No. 6300. The incidence is overestimated because there is a significant risk, although small, of thrombo-embolism after both open and closed mitral valvotomy and repair operations on the mitral valve when a prosthesis is not used (Kahn et al., 1966 ; Olinger, Rio, and Maloney, 1971; Ellis and Harken, 1961; Greenwood, Aldridge, and McKelvey, 1963).

The reduction in flow ratios with the newer valve introduces another factor in promoting stasis in the left atrium and thrombus formation (Kloster, Herr, Starr, and Griswold, 1969; Reis et al., 1970; Hodam et al., 1969). In our series early emboli were more common in patients with size 2 and 3 Starr-Edwards prostheses than in those with a size 4 . This early incidence has been improved with the introduction of the composite seat valve, which has a comparably greater orifice (Hodam et al., 1970; Reis et al., 1970; Kloster et al., 1970). One patient of the 19 who had a composite seat valve inserted late in the study had a fatal thrombosis of both aortic and mitral valves. A further 16 patients not included in the present study have shown no embolic episodes following composite seat valve insertion, giving a total embolic incidence of $3 \%$ for the 35 patients.

The incidence of early embolism was similar in patients who had multiple valve replacements as in those with single mitral valve replacements, confirming that patients with mitral valve replacement are at greater risk in the early postoperative period.

Our method of using warfarin to prevent these early episodes is unsatisfactory as embolus or thrombus on the valves had occurred before anticoagulant control could have been achieved and emboli occurred in two patients who appeared to be adequately controlled at the time. A trial using heparin early postoperatively did not appear to. make any difference to the incidence of thrombo embolism (Starr et al., 1967), but the administra tion of the drug was delayed until the fourthis postoperative day, and even earlier administration $\overrightarrow{0}$ may be necessary, although the risk from haemorrhage may be prohibitive. It is though that valve thrombus occurs early after operation and the preventative measures, as reported by Matloff et al. (1969), should begin as soon asoo possible postoperatively, that is when bleeding has ceased, to be effective. Platelet thrombi on the rough cloth covering of the prosthesis, before pseudo-endothelium covers the cloth, may be themost significant single cause of thrombo-embo lism with the prostheses studied. The administration? of dipyridamole in association with warfarin tợ prevent platelet aggregation may be worth while (Sullivan, Harken, and Gorlin, 1968). Unless the problem of early embolism is overcome, this prosthesis appears to offer no advantage over the older ball valve prosthesis and has the disadvan tage of a larger gradient across the valve (Klostero et al., 1969; Reis et al., 1970; Hodam et al., 1969)

Our findings confirm that the incidence of embolism is not influenced by the presence of $\overrightarrow{\overrightarrow{0}}$ left atrial thrombus at operation nor by a previous 3 mitral valvotomy (Matloff et al., 1969; Duvoisin et al., 1967). Neither did atrial fibrillation appear to influence the incidence, which is in contras to other reported series (Yeh, Anabtawi, Cornett and Ellison, 1967). The number of patients with $\times$ atrial fibrillation in our series was very high, $83 \%, \frac{0}{3}$ compared with $52 \%$ in the series of Matloff et at (1969). Transient atrial fibrillation was presento in the one patient with embolism who had had an aortic valve replacement. Postoperatives haemorrhage, severe enough to require re-opera $\frac{D}{0}$ tion, occurred in $50 \%$ of patients with earlye. emboli, all of whom had had mitral valve replace N ments. The overall incidence of embolism, $15 \%$ N was greater than that reported by Reis et al N (1970) at $12 \%$.

The reduction in serious late thrombo-embolism when compared to other series with the older prosthesis is encouraging. Our $9 \%$ incidence with the prostheses studied is more than the $6 \%$ repor ted by Hodam et al. (1969). For mitral valveo replacement alone the incidence is $8 \%$ in ourd series but only $3 \%$ in Hodam's. There was aक्षे higher incidence of late embolism after aortic valve replacement $(18 \%)$ in our series compared to $6 \%$ in Hodam's larger series. The incidence of 
late emboli is more common after aortic valve replacement in both series. Two of the six patients who had aortic valve replacement (Table V) were in atrial fibrillation at the time of embolism whereas none of the aortic patients without emboli were in atrial fibrillation. Fourteen of the 15 late emboli were minor with rapid recovery of the patient and no residual disability.

Stable anticoagulant control was difficult to achieve throughout. Many factors are involved, not least patient unreliability. This emphasizes the inherent difficulty of outpatient anticoagulant control and stresses the need for prostheses which will not require postoperative anticoagulants.

Anticoagulants are not without hazard. Death directly attributable to their use occurred in three of our patients; all died from massive cerebral haemorrhage.

When the cloth-covered prostheses No. 2300 and No. 6300 are used, valve occlusion or malfunction due to thrombus formation should be considered in the early postoperative period in patients in whom there is the slightest suggestion of minor embolism, persistent pulmonary oedema, or persistent dysrhythmias, and should be investigated promptly. Failure to do so may account for the high early mortality from thromboembolism, although the results of re-operation have been disappointing (Vander Veer, Rhyneer, Hodam, and Kloster, 1971 ; Gunstensen, 1971 ; Horsley, Rappoport, Vigoda, and Vogel, 1970). The solution lies in the prevention of thromboembolism by a change in valve design and a more effective medical regime to abolish platelet thrombi in the immediate postoperative period. Our early experience of the use of the composite seat valve is encouraging.

\section{REFERENCES}

Barnard, C. N., Goosen, C. C., Holmgren, L. V., and Schrire, V. (1962). Prosthetic replacement of the mitral valve. Lancet, 2, 1087.

Braunwald, N. S., and Bonchek, L. I. (1967). Prevention of thrombus formation on rigid prosthetic heart valves by the ingrowth of autogenous tissue, $J$. thorac. cardiovasc. Surg., 54, 630.

Brock, R. (1956). The surgical approach to the left atriumremoval of an atrial myxoma. Guy's Hosp. Rep., 105, 382.

Chin, H. P., Harrison, E. C., Blakenhorn, D. H., and Moacanin, J. (1971). Lipids in silicone rubber valve prostheses after human implantation. Circulation, 43 and 44, Suppl. 1, p. 51.
Duvoisin, C. E., Brandenburg, R. O., and McGoon, D. C. (1967). Factors affecting thromboembolism associated with prosthetic heart valves. Circulation, 35 and 36, Suppl. 1, p. 70.

Ellis, L. B., and Harken, D. E. (1961). Arterial embolization in relation to mitral valvuloplasty. Amer. Heart J., 62, 611.

Greenwood, W. F., Aldridge, H. E., and McKelvey, A. D. (1963). Effect of mitral commissurotomy on duration of life, functional capacity, hemoptysis and systemic embolism. Amer. J. Cardiol., 11, 348.

Gunstensen, J. (1971). Acute dysfunction of Starr-Edwards mitral prostheses. Thorax, 26, 163.

Hodam, R., Starr, A., Herr, R., and Pierie, W. R. (1969). Early clinical experience with cloth covered valvular prostheses. Ann. Surg., 170, 471.

—_ Raible, D., and Griswold, H. (1970). Totally cloth covered prostheses. Circulation, 41 and 42, Suppl. 2, p. 33

Horsley, H. T. Jr., Rappoport, W. J., Vigoda, P. S., and Vogel, J. H. K. (1970). Fatal malfunction of StarrEdwards low profile mitral valves. Circulation, 41 and 42, Suppl. 2, p. 39.

Kahn, D. R., Kirsh, M. M., Lennox, S. C., Sloan, H., and Penner, J. A. (1966). Embolism and the mitral valve. Surgery, 60, 136.

Kloster, F. E., Farrehi, C., Mourdjinis, A., Hodam, R. P., Starr, A., and Griswold, H. E. (1970). J. thorac. cardiovasc. Surg., 60, 879.

- Herr, R., Starr, A., and Griswold, H. (1969). Haemodynamic evaluation of a cloth-covered Starr-Edwards valve prosthesis. Circulation, 39 and 40, Suppl. 1, p. 119.

Matloff, J. M., Collins, J. J., Sullivan, J. M., Gorlin, R., and Harken, D. E. (1969). Control of thromboembolism from prosthetic heart valves. Ann. thorac. Surg., 8, 133.

Olinger, G. N., Rio, F. W., and Maloney, J. V. Jr. (1971). Closed valvulotomy for calcific mitral stenosis. $J$. thorac. cardiovasc. Surg., 62, 357.

Reis, R. L., Glancy, D. L., O'Brien, K., Epstein, S. E., and Morrow, A. G. (1970). Clinical and hemodynamic assessments of fabric-covered Starr-Edwards prosthetic valves. J. thorac. cardiovasc. Surg., 59, 84.

Roberts, W. C., Levinson, G. E., and Morrow, A. G. (1970). Lethal ball variance in the Starr-Edwards prosthetic mitral valve. Arch. intern. Med., 126, 517.

Spencer, F. C., Reed, G. E., Clauss, R. H., Tice, D. A., and Reppert, E. H. (1970). Cloth covered aortic and mitral valve prostheses. J. thorac. cardiovasc. Surg., 59, 92.

Starr, A., Herr, R. H., and Wood, J. A. (1967). Mitral replacement: review of six years experience. J. thorac. cardiovasc. Surg., 54, 333.

Sullivan, J. M., Harken, D. E., and Gorlin, R. (1968). Pharmacologic control of thromboembolic complications of cardiac valve replacement. New Engl. J. Med., 279, 576.

Vander Veer, J. B. Jr., Rhyneer, G. S., Hodam, R. P., and Kloster, F. E. (1971). Obstruction of tricuspid ball valve prostheses. Circulation, 43 and 44, Suppl. 1, p. 62.

Yeh, T. J., Anabtawi, I. N., Cornett, V. E., and Ellison, R. G. (1967). Influence of rhythm and anti-coagulation upon the incidence of embolization associated with Starr-Edwards prostheses. Circulation, 35, Suppl. 1, p. 77. 